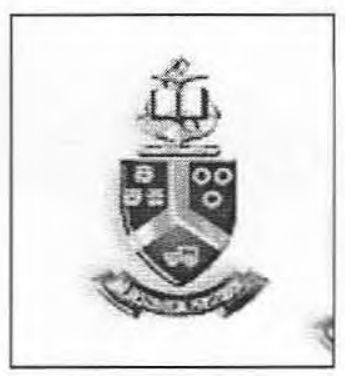

University of Pretoria

School of Health Systems and Public Health

\title{
The health and living conditions of children in child- headed households in Siteki, Swaziland
}

By

\section{Samantha Sibusisiwe Earnshaw}

Submitted in partial fulfilment of the requirements of the Degree

\author{
Master of Public Health \\ (Specialisation: Health Policy and Management) \\ In the \\ Faculty of Health Sciences
}

Supervisor: Dr. Zola Njongwe

August 2007 


\section{TABLE OF CONTENTS}

DEDICATION.

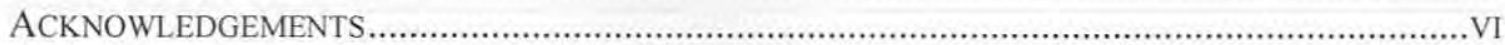

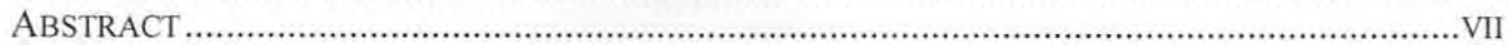

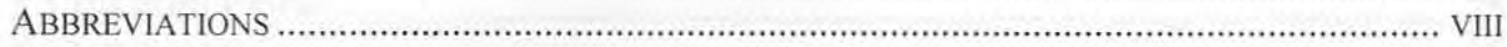

\section{PART 1 - BACKGROUND ......................... 1}

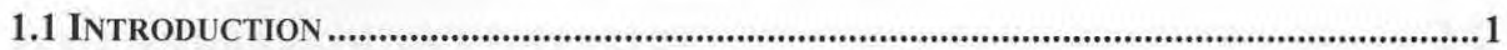

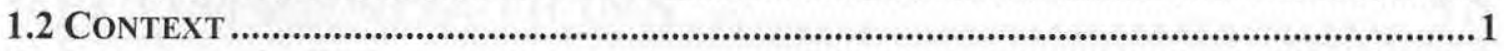

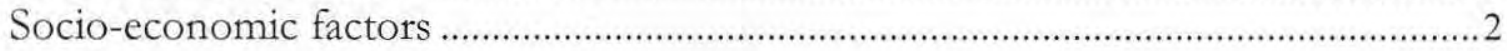

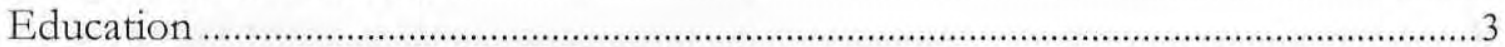

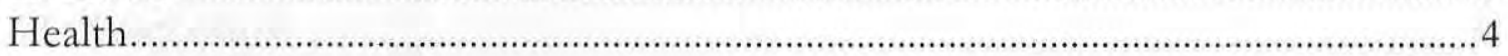

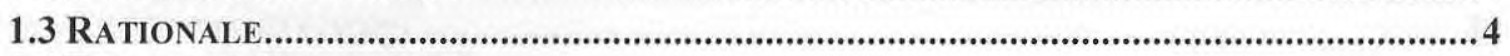

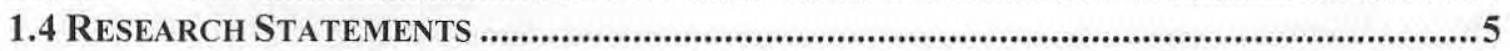

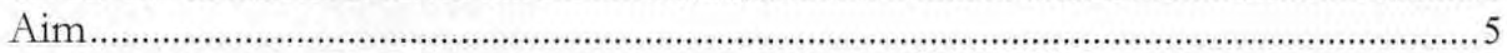

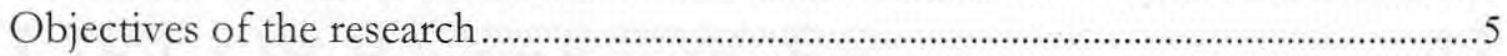

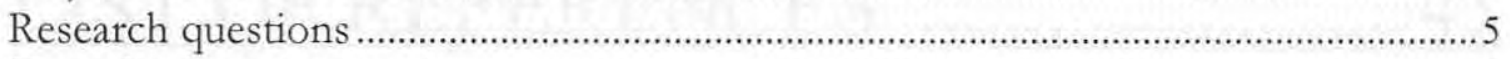

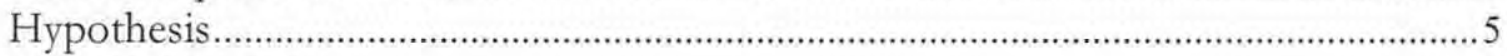

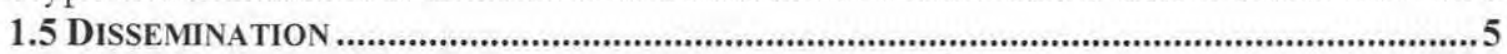

PART 2 - LITERATURE REVIEW ...................6

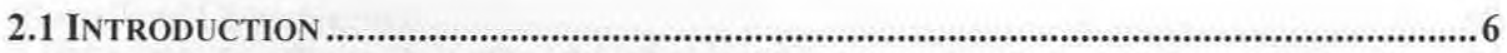

2.2 INITIATIVES IMPACTING CHILD-HEADED HOUSEHOLDS IN SWAZILAND............................ 6

PART 3 - METHODS ............................ 11

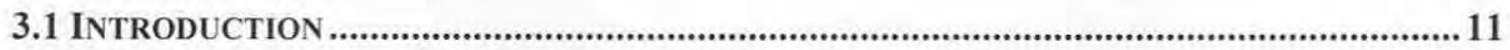

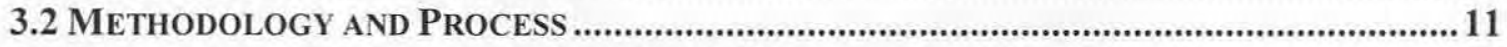

3.3 POPULATION, SAMPLING AND INCLUSION/EXCLUSION CRITERIA ...................................12

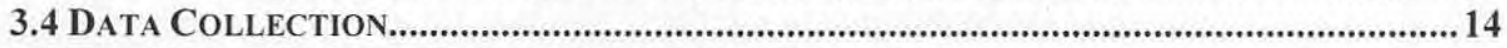

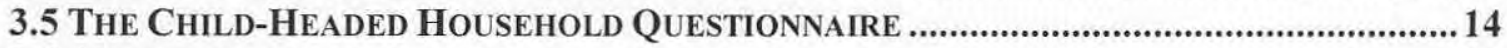

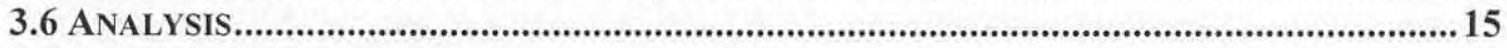

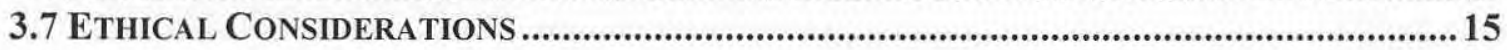


4.1 INTRODUCTION .16

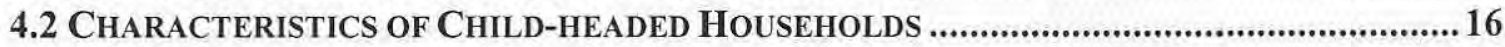

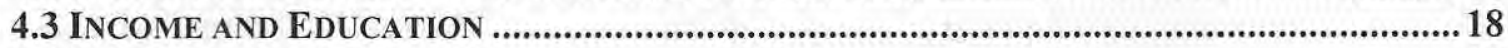

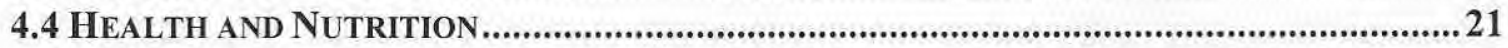

4.5 GOVERNMENT AND NGO PROGRAMMES: KNOWLEDGE AND USAGE ............................26

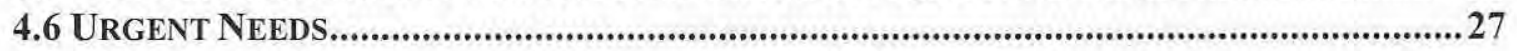

\section{PART 5 - DISCUSSION ..........................28}

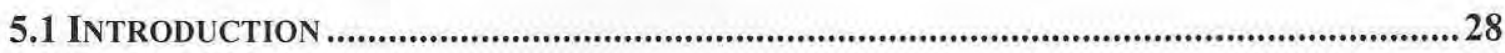

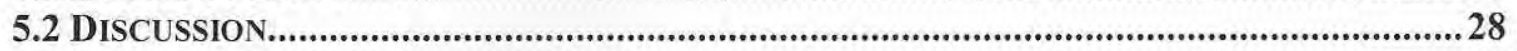

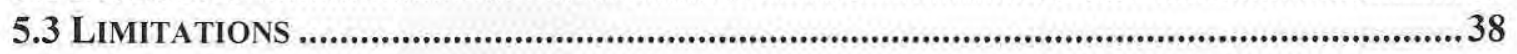

\section{PART 6 - CONCLUSIONS AND}

RECOMMENDATIONS .......................... 38

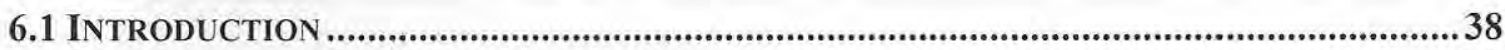

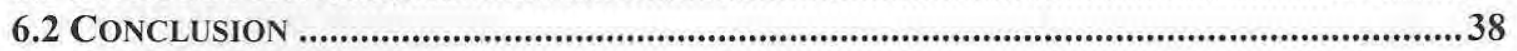

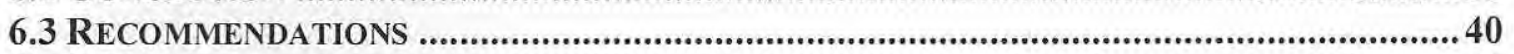

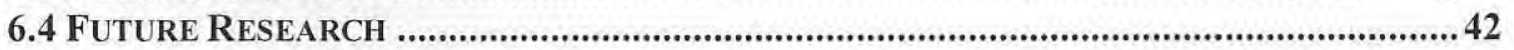

\section{LIST OF REFERENCES ................... 43}

\section{APPENDICES ...............................49}

APPENDIX A: Approval letter from University of Pretoria Ethics Committee......................49

APPENDIX B: Approval Letter from Ministry of Health and Social Welfare

(Swaziland Government).

APPENDIX C: Assent Form for 10 - 18 Year Olds ........................................................... 51

APPENDIX D: siSwati Version of Assent Form for 10 - 18 Year Olds..................................53

APPENDIX E: Child-Headed Households Questionnaire (EnglishVersion) .........................55 


\section{Dedication}

To the memory of my father Samuel Sydney Earnshaw 


\section{Declaration}

I, Samantha Earnshaw, declare that this dissertation, which I hereby submit for the degree in Master of Public Health (MPH) at the School of Health Systems and Public Health, Faculty of Health Sciences, University of Pretoria, is my own work and has not previously been submitted for other degrees or diploma purposes at any other institution. All sources used have been quoted and acknowledged by complete references.

Student's signature:

Supervisor's signature:

Date: Signed at:

Ethics Committee reference number: S203/2006

Date of approval: 21/11/2006 


\section{Acknowledgements}

I am thankful first and foremost to God for allowing my life to be filled over the past year and a half with new experiences and friends. I am especially grateful to the children who participated in this study. I appreciate all the assistance I received from my enumerator and translator Gugu Zikalala and Mrs. Estelle Dlamini, who did a great job at translating my document into siSwati. The numerous community members (too many to mention here by name), head teachers and their schools cannot be thanked enough for their support during this study. Special thanks go to Mr. Eric Maziya, Director of the Social Welfare Department, and Mrs. Jabu Dlamini, of the Ministry of Regional Development and Youth Affairs in Swaziland. I find it very encouraging that there are still people with your passion that are working for our children and us. I appreciate you.

A big thank you goes to Dr. Zola Njongwe, my supervisor, advisor and lecturer in Health Management and Policy at the University of Pretoria's School of Health Systems and Public Health. The value of her comments and encouragement cannot be over-estimated. I appreciate her honesty, professionalism and humour. You gave the "pulls" and the "shoves" at just the right times! I thank you endlessly.

This time of enjoyment and learning is due, in no small part, to the professors, students, and staff of the School of Health Systems and Public Health. I am thankful to the University for its partial funding for this study. I would like to remember Liz Wolvaardt, Reuben Sehone and Barbara English for their support which, whether they knew or not, was much appreciated. I am especially gratefully to Dr. Andy Beke for the learning opportunities afforded me by him. Also, Zeleke Worku for his time, knowledge and assistance in statistical matters that I was unfamiliar with.

Forget-you-nots: My colleagues and newest friends - thanks for the encouragement and much needed laughter. Thanks to (Aunt) Nompi Dunn, Zola Mtetwa, Malika Magagula and Lesego Bogatsu for opening your homes to me when I needed a place to lay my head in South Africa.

Also with love and thanks to my grandmother Marjorie B. Miller, and my sister and brother-in-law, Amelia and Mbono Motsa for their assistance with food parcels for the families that participated in this study.

And, finally, I am forever grateful to my mother, Pat Earnshaw, without whose love, money and endless patience, I could not have achieved any of this. I love you. 


\section{Abstract}

In Swaziland it is estimated that approximately $10-15 \%$ of the entire population will be orphans and other vulnerable children by 2010 and that one in ten households in the country today are child-headed because of the impact of HIV and AIDS. As the epidemic continues to devastate families and affect incomes, the traditional safety nets of family and community are stressed and assistance to these children is infrequent at best. The focus of this study is to determine the health and living conditions of children living in these types of households. The population comprised 41 heads of household, caring for 97 siblings among them. Data was collected in a single period between the months of February and April 2007 using the Convenience sampling and employing a semi-structured questionnaire. Children were generally physically healthy, despite not receiving adequate food or balanced diets. Most had access to health facilities or at least sources of medication. Education assistance exists but is limited and abuse was generally not reported due to fear of reprisal. There is a dearth of information on adolescents in Swaziland, the primary caregivers in most child-headed households. Children are not actively consulted and encouraged to participate in helping to solve the problems they are affected by. There is a lack of coordination between caregiver organisations, leading to ineffective and inefficient service provision for this particular vulnerable group. This report gives recommendations for ways in which to begin to overcome these issues, as well as suggestions for further research to better understand, prevent and assist child-headed households. 


\section{Abbreviations}

AIDS

AMICAALL

AU

CBO

$\mathrm{CHH}$

CRC

ECHO

FBO

FLAS

$\mathrm{HH}$

HIV

KaGogo

Lutsango

LL

MoHSW

NERCHA

NCP

NGO

NPA

OVC

PHC

PSS

RHM

SOS

TIBIYO

TINKUNDLA

TB

UNICEF

WFP

WHO

WV
Acquired Immune Deficiency Syndrome

Alliance of Mayors' Initiative for Community Action on AIDS at the Local Level

The African Union

Community-based Organisation

Child-headed Household

United Nations Convention on the Rights of the Child

European Commission's Humanitarian Aid Office

Faith-based Organisation

Family Life Association of Swaziland

Head of Household

Human Immunodeficiency Virus

Community Social Centres ("Grandmother's house")

Lutsango IwakaNgwane Traditional Women's Regiment

Lihlombe Lekukhalela - Community Counsellors

Ministry of Health and Social Welfare

National Emergency Response Council on HIV/AIDS

Neighbourhood Care Point

Non-Governmental Organisation (local and international)

National Plan of Action for Orphans and Vulnerable

Children

Orphans and other Vulnerable Children

Primary Health Care

Psychosocial Support

Rural Health Motivator

SOS Children's Villages

Tibiyo Taka Ngwane (The King's Trust Fund)

Swaziland Constituencies

Tuberculosis

United Nations Children's Fund

World Food Programme

World Health Organization

World Vision 